\title{
THE SANDSTONE KARST OF PINE COUNTY, MINNESOTA
}

\section{Beverley L. Shade}

School of Nursing, University of Texas, 4811 Duval St., Austin, Texas, 78751, USA,

bev_shade@yahoo.com

\section{E. Calvin Alexander, Jr.}

Earth Sciences Department, University of Minnesota, 310 Pillsbury Dr. SE, Minneapolis, MN 55455, USA,

alexa001@umn.edu

\section{Scott C. Alexander}

Earth Sciences Department, University of Minnesota, 310 Pillsbury Dr. SE, Minneapolis, MN 55455, USA, alexa017@umn.edu

\section{Abstract}

The glaciated, forested landscape of central Pine County in east-central Minnesota contains a series of sinkholes, stream sinks, springs and caves. The features are formed in Precambrian Hinckley Sandstone and overlying unconsolidated glacial deposits. This is a sandstone karst. The features serve the same function as in carbonate karst terrains: sinkholes and caves focus recharge into a heterogeneous subterranean flow system that discharges into springs. The Hinckley Sandstone is a quartz arenite. No carbonate grains or cements have been found in sandstone samples from the sinkhole area, nor is there evidence that calcite solution controls bedrock permeability. Three parameters appear to control the distribution of sinkholes: depth to bedrock, type of underlying bedrock, and meter-scale heterogeneity of surface sediments. The permeability structure of the Hinckley Sandstone appears to be controlled by fractures and depositional features at centimeter to meter scale. Field mapping in the area has revealed 309 karst features: 237 sinkholes, 25 stream sinks, 32 springs and 15 caves. Recent LiDAR coverage indicates that there are many more sinkholes and other karst features than the original mapping was able to locate. Interpretation of the LiDAR images is challenging because karst processes, glacial processes and human activity have all produced natural and anthropogenic closed depressions of a variety of sizes and shapes in this landscape.

\section{Introduction}

\section{Definitions of Karst}

According to White (1988), karst can be defined as a combination of process and form, where process is dominance of chemical over mechanical erosion and form is a set of distinctive geomorphic features. When solution and mechanical erosion compete, solution must be the more dominant process in order for the resulting landforms to be considered karst. Similar landforms that owe their development to other causes are often termed 'pseudokarst'.

Others have developed broader definitions. In his treatment of some puzzling features on sandstone, Jennings (1983) defines karst as the result of "the process, solution, which is thought to be critical (but not necessarily dominant) in the development of the landforms and drainage characteristics of karst." $\mathrm{He}$ defines pseudokarst as "country with resemblances to karst, which are due to other processes."

Jennings' definitions acknowledge that karst is more than a geomorphic landscape; it is more useful to consider karst as a system, with a definition based on universal characteristics instead of lithology. These characteristics include interconnected networks of flow paths capable of high-velocity and turbulent flow. Karst flow systems have "a specific type of fluid circulation capable of selfdevelopment and self-organization" (Klimchouk and Ford, 2000). Considering karst as a flow system focuses on the essence of what distinguishes karst flow from porous media flow.

\section{Global Distribution of Silicate Karst}

While karst and pseudokarst occur in a variety of lithologies, our focus is on nearly monomineralic silicates such as quartz arenite or orthoquartzite. Solutional karst features in these lithologies have been recognized on all continents, in a range of climates. Wray's (1997) review paper notes silicate karst in Venezuela, Brazil, the United States, Morocco, Chad, Niger, Nigeria, Zimbabwe, South Africa, Thailand, Australia, the United Kingdom, Poland, the former Czechoslovakia, and scattered sites 
across western Europe. Caves with depths of nearly 400 meters and lengths up to several kilometers have been documented in silicate karst regions, demonstrating a local significance simply in terms of pervasiveness and scale (Truluck, 1991; Wray, 1997). Not included in Wray's list are sinkhole-topped mesas in northwestern New Mexico (Wright, 1964), solution pans in the Gobi Desert of Mongolia (Dzulynski and Kotarba, 1979), and the sinkholes of northeastern Minnesota discussed in this paper (Shade, 2002a).

\section{Previous Work}

Interest in solutional sandstone features began as early as the work of Frye and Swineford (1947), with descriptions of surficial forms. This characterizes much of the early descriptive research on sandstone weathering, in which chemical reactions or factors underlying development were rarely addressed and form implied process (Turkinton and Paradise, 2005). However, investigations on the genesis of sandstone karst features have occurred in both Australia and Venezuela, as discussed below.

The Roraima region of southeastern Venezuela and northwestern Brazil hosts a globally known silicate karst and has attracted attention from researchers since the late 1950's. Early work in the Roraima Quartzite includes White et al. (1966), who explored the idea that geomorphic features on large table mountains (tepuis) could be formed by solution. Since the solubility of amorphous silica is significantly higher than that of quartz and trace amounts of opal were found in rock samples, they postulated that quartz cements had been hydrated to opal and later removed by meteoric waters.

Zawidzski et al. (1976) also called on large-scale alteration to accelerate solution of the Roraima Quartzite. They suggested that aggressive hydrothermal fluids from nearby granitic intrusions could dissolve quartz cements along structural features. Resulting weak areas would become preferential flow paths for meteoric waters when the rocks were exposed to surficial weathering. In this model, solution occurs long before the bedrock is exposed at the ground surface. During surficial weathering, material is removed by mechanical forces. This theory does not address silica-based precipitates documented in the region that imply an active role of solution in the modern flow system.
Chalcraft and Pye (1984) found the solubility of geologic opal to be up to four times lower than that of experimental amorphous $\mathrm{SiO}_{2}$, so that opal hydration is not a necessary step in the solution of quartz. They also note that the solubility of all forms of $\mathrm{SiO}_{2}$ can be enhanced by alginic and amino acids produced by algae. The tops of the Roraima tepuis have widespread colonies of algae and accumulations of organic material in bogs, unlike the surrounding lowlands. They present SEM (scanning electron microscope) images with features (etching of quartz grains and cements) that they attribute to solution. They argue that solution is critical to the development of the Roraima karst.

In northwestern Australia, Young (1986; 1987) describes the geomorphic features of several sandstone karsts. He addresses speleogenesis through petrographic studies to look for microscopic solution features, as well as variation (such as primary porosity at the onset of dissolution, or structural and depositional controls) that could explain the distribution of landforms. Young (1988) reports extensive etching of grains and optically continuous overgrowths in SEM images. He documents two main etching textures. The first are v-shaped notches that show strong crystallographic control. These are surface reaction controlled features, indicative of slow fluid movement. The other group is that of embayments; a single embayment can cross a grainovergrowth boundary, which does not happen with v-notches. Embayments are flow-controlled features, indicative of higher fluid velocities (Young, 1988).

\section{Geological Setting of the Field Area}

The study area lies in central Pine County, which is located in east-central Minnesota. Mesoproterozoic basalts are overlain by the Fond du Lac Sandstone, which is overlain by the Hinckley Sandstone (Figure 1). Two large northeast-southwest trending reverse faults (the Douglas Fault and Hinckley Fault) have uplifted terrain to the east: in the east part of the study area, basalts are exposed at the surface, in the central part of the study area the Fond du Lac Sandstone is covered by a veneer of Hinckley Sandstone, and the west part of the study area is covered by a layer of Hinckley Sandstone up to 150 meters thick (Boerboom et al., 2002; Mooney et al., 1970). The stratigraphy and faults are associated with the northern part of the western limb of the failed Midcontinent Rift System 


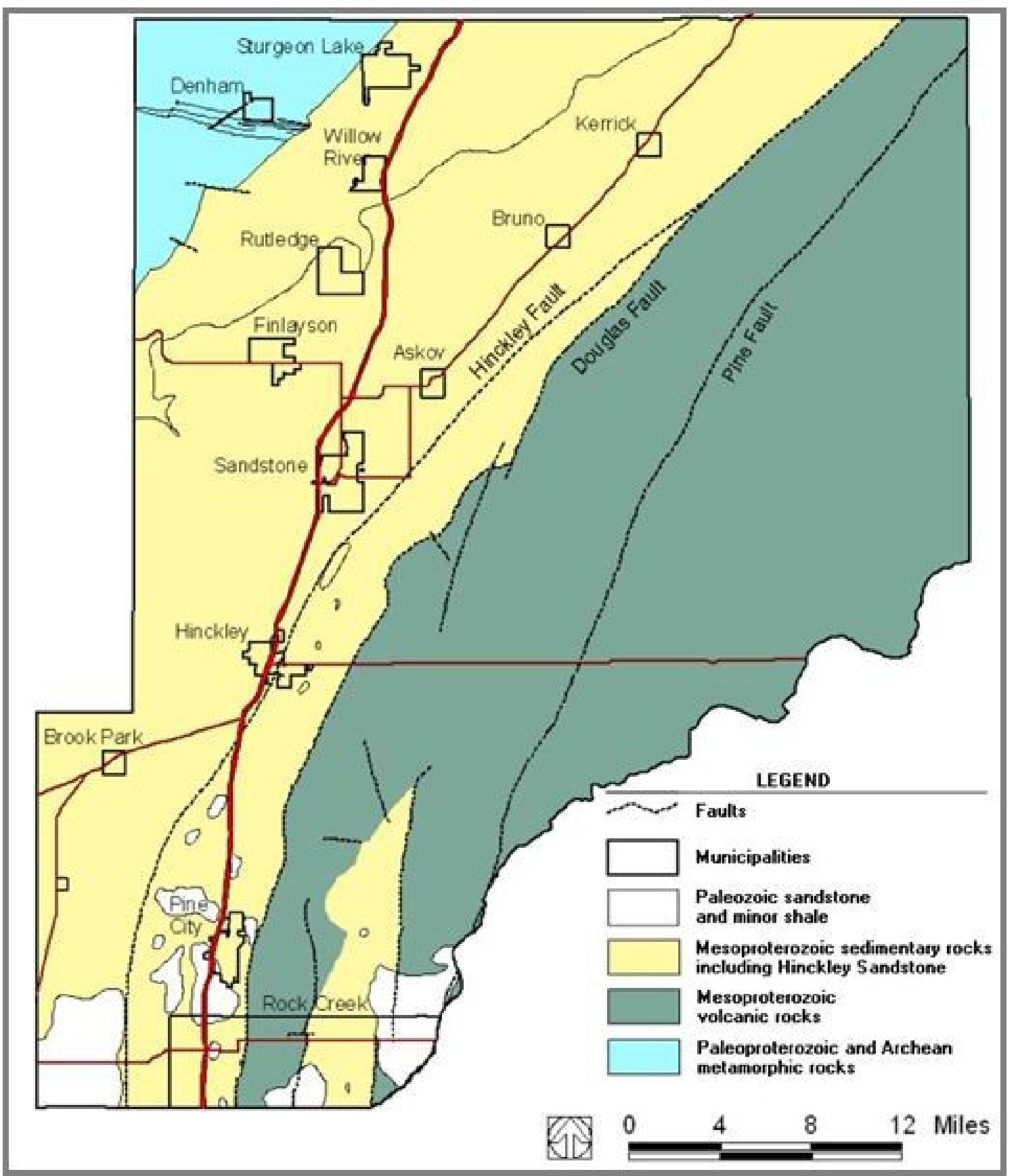

Figure 1. Location map of Pine County with bedrock geology (adapted from Boerboom, 2001). The bold red line connecting Hinckley, Sandstone and Willow River is 135 . The red line connecting Askov and Bruno is MN 23.

(Boerboom et al., 2002). In the study area, volcanism associated with rifting ended after 1094 mya. Some rift grabens were partially inverted to form horsts; the study area abuts the western edge of the St. Croix Horst. The St. Croix Horst consists of a suite of uplifted volcanic rocks that are flanked on both east and west sides by basins of younger and contemporaneous rift-derived sediments (Cannon et al., 2001).
The basins adjacent to the Midcontinent Rift System contain thick sequences of sedimentary rocks. The Fond $\mathrm{du}$ Lac Sandstone it may be as thick as $2-3 \mathrm{~km}$ at its eastern boundary, and thins westward, away from the rift zone. The Hinckley Sandstone is up to $500 \mathrm{~m}$ thick at the Hinckley Fault, and thins westward (Mooney et al., 1970). Morey (1972) interpreted the lithology and sedimentary structures of the Fond du Lac as shallow 
water delta deposits. The Hinckley Sandstone appears to be primarily composed of reworked Fond du Lac materials (Morey, 1972). It is described by Tryhorn and Ojakangas (1972) as a tan to orange, fine- to mediumgrained quartz arenite that is typically about $96 \%$ quartz, well sorted and well rounded. The base of the Hinckley Sandstone is exposed in a thin layer between the Hinckley and Douglas Faults, where it contains small quantities of other lithic elements and is classified as feldspathic arenite (Boerboom et al., 2002).

The surficial geology of Pine County is dominated by glacial deposits and landforms sculpted by glacial advance and retreat. During the Wisconsinan Glaciation of the Mid- to Late Pleistocene, the Superior Lobe moved into the county from the north and at its maximum covered the entire county. The Superior Lobe retreated and advanced across Pine County at least twice (Knaeble et al., 2001).

Karst features occur over five different surficial map units (Patterson and Knaeble, 2001). All are unconsolidated Pleistocene deposits in the Sandstone and Aksov Lookout Tower phases (or ice margins) of the Superior Lobe. Surficial units where sinkholes have been mapped include Qsgs, which is described as "sandy glacial sediment", Qsgf, which is described as "silty and clayey glacial sediment", Qssi, which is dominantly sand and gravel, described as "sorted sediment proximate to ice", and Qssm, described as "sandy glacial sediment" (Patterson and Knaeble, 2001).

\section{Methods Field Mapping}

In the first phase of this work karst features were found by field mapping, both by systematic walking surveys and by talking to local residents. All reported features were field verified. Locations were mapped by GPS, and entered into a GIS database. The karst survey initially focused on Partridge Township, and later extended into the townships of Bruno, Finlayson, and Sandstone. The entire area underlain by Hinckley Sandstone was not surveyed. Every sinkhole in the surveyed areas has not been located; additional features will certainly be discovered both in these area and other parts of Pine County.

\section{Sinkhole Excavations}

Several sinkholes were excavated in order to understand how they formed. The features were selected based on setting, size and morphology. Three were dug open with hand tools and two were opened by backhoe. For all five features, a trench with vertical sidewalls was excavated perpendicular to the most likely bedrock fracture orientations. Surface profile and stratigraphy were measured every $10 \mathrm{~cm}$ along the trench, using leveled strings as a vertical reference. Trenches were excavated as deep as possible within the constraints of safety, time, and the water table. In one case, we used a truckmounted Giddings Soil Probe to make a series of cores in and around a sinkhole to better define stratigraphic relationships that were too deep for hand excavation.

\section{LiDAR Analysis}

A second phase of mapping is currently underway. The recent availability of $1 \mathrm{~m}$ resolution LiDAR data for Pine County allows for more systematic and complete mapping of karst features. We are visually scanning shaded relief DEMs (Digital Elevation Models) at varying scales down to about 500:1. Locations of potential sinkholes are recorded in a GIS environment in the Minnesota Karst Features Database, maintained by the Minnesota Geological Survey (Tipping et al., 2015).

The locations of sinkholes identified by Shade (2002a) are compared to newly mapped potential karst features to help determine how to differentiate sinkholes from other closed depressions present in Pine County on the DEMs, such as glacial and anthropomorphic features.

\section{Petrology}

The permeability structure of the Hinckley Sandstone was investigated at the outcrop, hand sample, and microscopic scales. Outcrop observations were made by observing depositional features and measuring structural features in outcrops along the Kettle River. Hand samples were collected from one outcrop and oven dried for several days at $60^{\circ} \mathrm{C}$. Cubes measuring approximately $4 \mathrm{~cm}$ per side were placed in a vacuum chamber and impregnated with colored thin section epoxy. After the epoxy cured, blocks were cut open to assess the penetration of epoxy. Finally, sand grains from the hand samples were imaged with a scanning electron microscope (SEM) to observe grain surface textures.

\section{Results}

\section{Features Found by Field Mapping}

In the initial phase of this project, field surveys located 309 karst features, which includes 237 
sinkholes, 25 stream sinks, 32 springs, and 15 caves as shown in Figure 2 (Shade et al., 2002b, 2002c). The sharp boundary along the southeast margin of the sinkhole array appears to be an actual boundary of the occurrence of sinkholes. That boundary roughly corresponds to the Hinckley Fault. The edges of the array to the north and west are undefined, and reflect only the limit of field surveys.

\section{Excavation of Selected Sinkholes}

We excavated five features, three with hand tools and two by backhoe. Four of the excavated features were sinkholes, formed by active transport of material into the subsurface by water. The fifth feature appeared to be of glacial origin. The cross section diagrams from two of the sinkholes are presented here.
Sinkhole D144 is part of a cluster of sinkholes located in Banning State Park, on top of the bedrock surface on the east of the Kettle River gorge. When found, it was 2.5 by $2 \mathrm{~m}$ in diameter and $0.7 \mathrm{~m}$ deep. A 4-m-long by 2-m-deep trench in glacial till exposed a funnel-shaped deposit of organic-rich soil cutting vertically through the till. At the limit of excavation, a small open drain continued into the subsurface (Figure 3). Excavation by hand tools did not reach the bedrock surface, and the location of the sinkhole in the state park eliminated the possibility of mechanical excavation or soil boring as were used in three other excavations.

Sinkhole D222 is part of a cluster of sinkholes located 5 $\mathrm{km}$ further south along the Kettle River. This cluster is also located in Banning State Park, on top of the cliffs

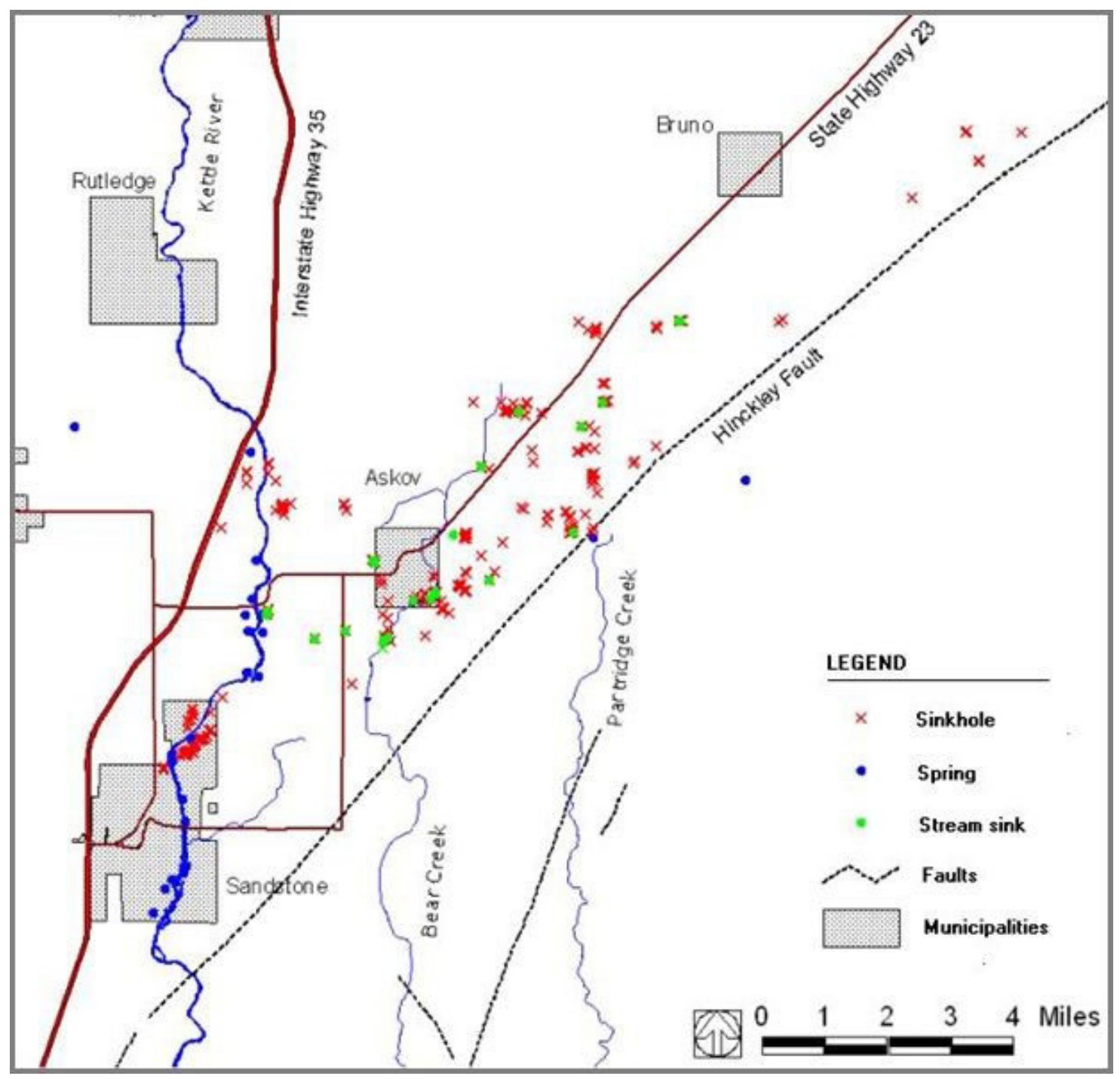

Figure 2. Karst feature distribution (Shade, 2002a) and bedrock faults in the study area. 


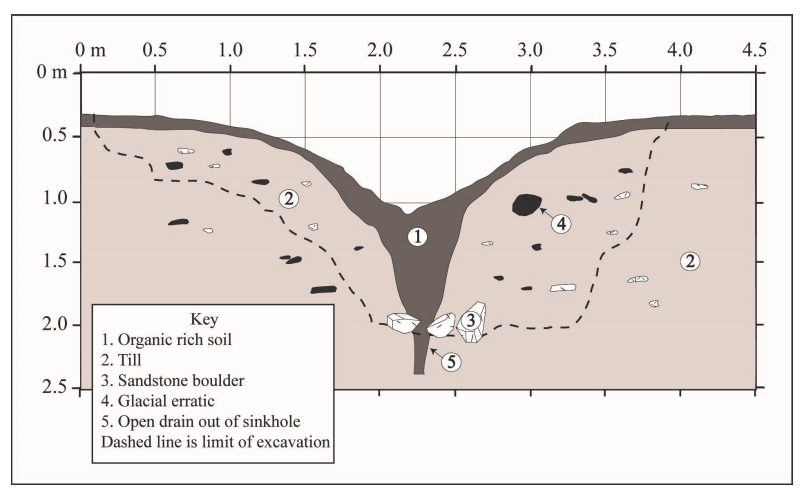

Figure 3. Subsurface profile of sinkhole D 144. Stratigraphy uncovered by excavation in sinkhole D 144 shows a crosscutting relationship of recent organic material being transported into the subsurface.

east of the Kettle River. This cluster of sinkholes forms a linear northeast-southwest trend that aligns with a group of karst features on the opposite side of the river, and runs parallel to the adjacent reach of the Kettle River. When found, the sinkhole was about $6 \mathrm{~m}$ in diameter by $0.8 \mathrm{~m}$ deep. A 4.5 -m-long by 2.25 -m-deep trench in glacial loess and till exposed a central funnelshaped deposited of sandstone boulders and leached organic material cutting vertically through the glacial deposits. At the limit of excavation, a small open drain continued into the subsurface. Excavation by hand tools did not reach the bedrock surface, and the location of the sinkhole in the state park precluded the use of mechanical excavation or soil boring as were used in three other excavations.

Sinkhole D355 is located south of the town of Askov, in a shallow stream bottom near municipal sewage lagoons. At the time of excavation, it was a large shallow sinkhole ( 10 by 12 meters in diameter by $<1$ meter deep) containing several smaller sinkholes. The largest was 1.5 by 2 meters in diameter by 0.5 meters deep, and was indicated by the landowner as the main drain for feature. A 9 -m-long by 4.5 -m-deep trench was excavated by backhoe. The trench exposed soil and stream deposits overlying glacial till, with a horizontal bedrock surface at $4.5 \mathrm{~m}$ depth. The stream sediments and till were cut by an irregularly shaped unit of organic material and reworked till with one branch coming from the main sinkhole drain and another issuing from the north wall of the trench. The two branches converged at a depth of about 3 meters and continued down toward an enlarged bedrock fracture in the base of the trench.
Sinkhole D127 is located in the northeastern part of the study area, in a field about $8 \mathrm{~km}$ east of the Kettle River. When found, it was a recent collapse where a 1.3 by 1.4 $\mathrm{m}$ plug of soil and grass had dropped $0.8 \mathrm{~m}$. The topsoil was undercut on the north and west sides, so that the sinkhole had an actual diameter of 2 meters. A 3-m-long by 3.25 -m-deep trench exposed horizontally layered glacial sediments of loess, sand, clay, and till (Figure 4). These sedimentary layers were cut by a vertical funnelshaped deposit of loose sand similar to layer 3 in Figure 4. Excavation by hand tools did not reach the bedrock surface, and a series of soil borings indicate a weathered bedrock surface at a depth of about $4 \mathrm{~m}$, and an intact bedrock surface at a depth of about $5 \mathrm{~m}$. In the throat of the sinkhole the bedrock is about $0.5 \mathrm{~m}$ deeper, forming an asymmetrical funnel in the rock surface which narrows to a much small area, ostensibly an enlarged fracture. Here the soil boring reached $7 \mathrm{~m}$ depth without hitting bedrock.

Feature D326 is located in a field $0.7 \mathrm{~km}$ south of D127. At the time of excavation, it was a closed depression about 30 by 40 meters in diameter by 3 meters deep. A 13-m-long by 3-m-deep trench was excavated by backhoe. The trench was characterized on its north end by sand and gravel mixed with large sandstone boulders,

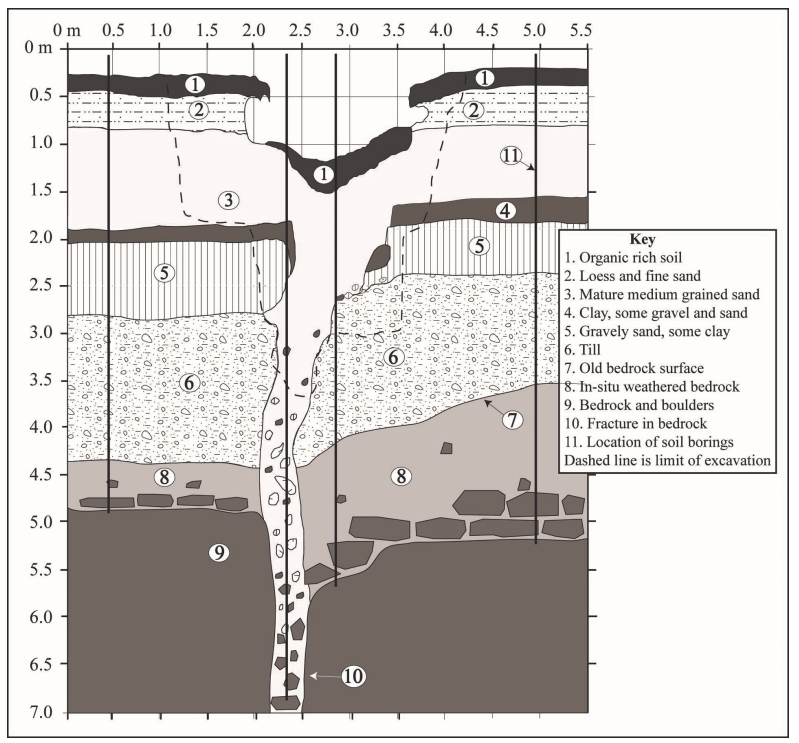

Figure 4. Subsurface profile of excavations in Sinkhole D127. Stratigraphic unit 3 has been vertically displaced at least five meters downward into the underlying bedrock fracture. Clasts of units 4, 5, and 6 were also present within the collapse funnel. 
and hosting small deposits of sand, peat. The south end of the trench was composed of glacial till with a small deposit of clay and spare sandstone cobbles. This closed depression did not have cross-cutting stratigraphy, a collapse funnel, or an open drain as seen in the other excavated sinkholes, and it appears to be of entirely glacial origin.

\section{Sinkholes Found by LiDAR}

Figure 5 shows a part of the southeast quarter of section 3, T42N, R20W on the southeast side of the Kettle River in Banning State Park. This area contains a dense array of sinkholes. Forty-two sinkholes were field mapped by the first phase of this research (Shade, 2002a). About half of the sinkhole locations were adjusted to fit the sinkholes visible in the LiDAR DEM and are shown as the green triangles in Figure 5. Locations were adjusted by a few meters to tens of meters and reflect the lower accuracy of the original GPS locations in comparison with the LiDAR elevation model.

Figure 6 shows the same area with the new LiDAR located sinkholes as red triangles. Seven additional sinkholes are visible in the DEM that were missed in the field work. The smaller field-located sinkholes are not visible in the DEM.

Figure 7 shows the DEM of section 3 of T42N, R20W and includes the area shown in Figures 5 and 6. Field work reported in Shade (2002a) located 64 sinkholes in Section 3 but did not cover the entire section (the green triangles). Visual scanning of the LiDAR DEM

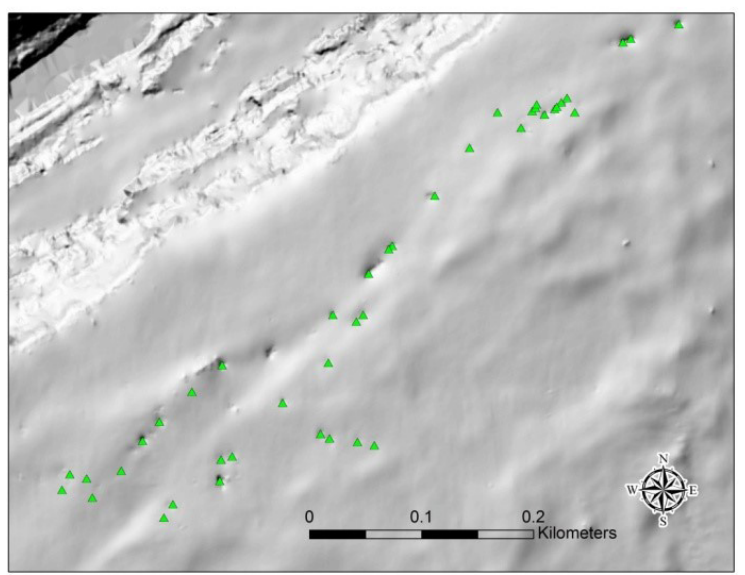

Figure 5. Sinkholes from Shade (2002a) (the green triangles) superimposed on a $1 \mathrm{~m}$ LiDAR DEM. Locations have been adjusted as per text description.

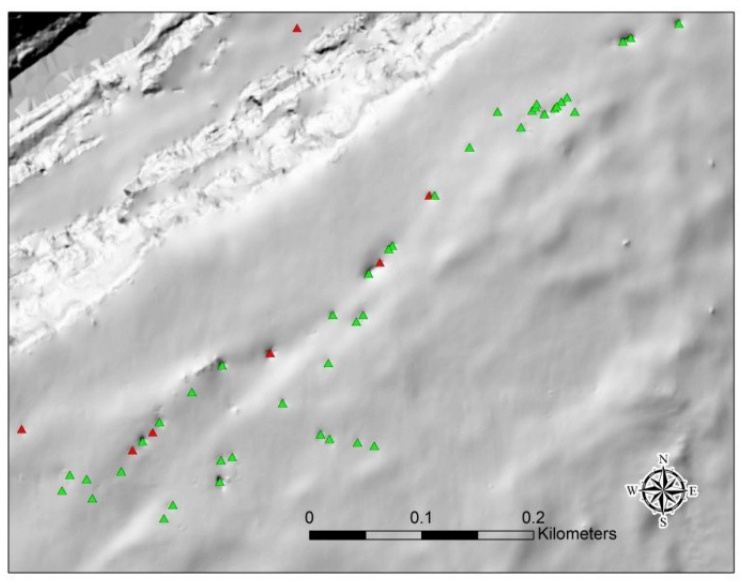

Figure 6. Sinkholes from Shade (2002a) (the green triangles) with potential sinkholes identified from the LiDAR DEM (the red triangles).

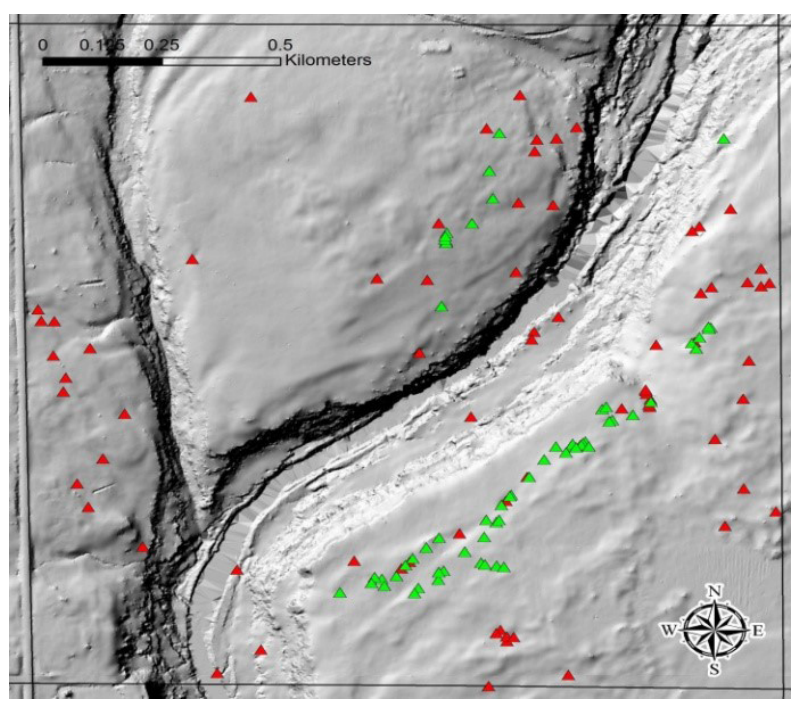

Figure 7. Sinkholes from Shade (2002a) with potential sinkholes identified from the LiDAR DEM. Sec 3 Findlayson Twp (T42N, R20W), Pine County.

identified 137 more potential sinkholes. Some of the new features are in areas previously surveyed, while others are outside of prior survey areas.

\section{Petrology}

The most available and extensive outcrops of Hinckley Sandstone are located in historical quarries and in the valley along the Kettle River. Some outcrops are formed by hard, well-indurated rock, while nearby outcrops may have rock that is soft and friable. There are noticeable variations of rock strength and weathering patterns within outcrops. Many outcrops showed enlarged fractures, enlarged bedding planes, and small $(<1 \mathrm{~m}$ 
diameter) conduits. The development of solutional features was not uniform in outcrop, but rather appeared to be controlled by lithology. Some sandstone beds or groups of beds had many solution features while those beds above and below had no visible solution features.

Saturation of hand samples with epoxy demonstrated a range of flow patterns. Some were uniform, with equal penetration by epoxy in all directions. However, most were not uniform, showing penetration that was retarded by a weathering crust, as well as sharply heterogeneous patterns following or avoiding bedding features, and following or avoiding tiny fractures.

Individual grains were imaged with SEM to observe grain surface textures. The SEM work was exploratory and does not represent an exhaustive survey of the Hinckley Sandstone. On the basis of preliminary investigation, sand grains from the surface of conduits seen in outcrop were characterized by extensive etching, pitting, and embayments. Grains from outcrops without obvious conduits, enlarged fractures, or bedding planes had the same types of solutional surface textures, but to a much lesser extent.

\section{Discussion}

Karst development in Pine County appears to be controlled by bedrock type and geologic structure. All mapped features occur over or in the thickest part of the Hinckley Sandstone, northwest of the Hinckley fault. Most features lie within five kilometers of the fault, and none have been mapped more than seven kilometers from it (Figure 2).

No sinkholes have been found in the thin layer of Hinckley Sandstone southeast of the fault, despite extensive field searching. Nor have any likely sinkholes been identified through LiDAR imagery mapping. To the northwest, there is not such a well-defined edge to the karst. This area has not been well searched, so the absence of sinkholes may be an artifact of field activity. Sinkhole formation would be less likely near the Hinckley-Fond du Lac contact northwest of the study area because the base of the Hinckley has a higher content of non-quartz material that could clog a developing flow system.

The thickness and composition of glacial sediments are also important in determining where sinkholes are likely to form. In places where the glacial drift is thin, surface water is able to move relatively quickly into the underlying bedrock. Areas of high transmissivity within the glacial drift such as sand lenses, gravel lenses or boulder concentrations also permit the surface water to move downward rapidly. Thus, areas with thin, coarse, and highly permeable drift underlain by fractured bedrock are most favorable for sinkhole development.

The sinkholes lie near the Askov Lookout Tower ice margins from the Superior Lobe of the Wisconsinan glaciation, but the causal relationship between the moraines and sinkhole distribution is uncertain. High volumes of unsaturated water resulting from glacial discharge may have enhanced solution of quartz. Discharge of glacial melt water off the front of the moraines may also have cleared fine-grained sediment from joints in the underlying bedrock. Such open joints could subsequently act as subsurface conduits over which the sinkholes could form. The movement of surface sediment into the underlying fractures/conduits is an ongoing process as demonstrated by the recent collapse of sinkhole D127 (Figure 4).

Excavation of closed depressions shows that some are true sinkholes, characterized by cross-cutting stratigraphy and active movement of surface material into the subsurface. The sinkholes occur in a range of sizes, from meters to tens of meters in diameter. In addition to sinkholes, this landscape also contains large depressions formed by glacial processes, and small depressions formed by stump holes. These features are distinguished from sinkholes because they are filled with sediments that are oldest on the bottom, youngest on the top, and without subsidence features or cross-cutting stratigraphy. This landscape also contains depressions of a range of sizes formed by human activity, such as gravel mining. These depressions are characterized by chaotic fill, and may not have any appreciable recent deposition.

Epoxy experiments indicate that the Hinckley Sandstone has a heterogeneous permeability structure at the hand sample scale. Outcrop observation shows weathering heterogeneity at the meter scale. Karst feature distribution indicates discrete high-velocity flow paths with strong structural control. SEM imaging of sand grains show surface textures attributed to solution in previous work.

Although scanning of the LiDAR DEM is just beginning, it is clear that the sandstone karst of Pine County is more 
extensive than documented in the first phase, where time and resources limited the initial field surveys. Pine County may prove to have second highest number of sinkholes in Minnesota, second only to Fillmore County.

\section{Conclusions}

Central Pine County hosts a karst system developed in sandstone. Surface karst features include sinkholes, streamsinks, and springs. These surface features are connected by a system of high-velocity flow paths seen in caves and enlarged bedrock fractures. Previous field mapping was limited by access to private property, as well as the scale of area to be surveyed. New LiDAR imaging could be a powerful tool to improve karst mapping by identifying potential features. Given that sinkholes are overprinted on a glaciated terrain, features identified by LiDAR must be field verified.

\section{Acknowledgments}

This work was supported by the Pine County Soil and Water Conservation District, the Department of Earth Sciences at the University of Minnesota and the Minnesota Geological Survey. We value the assistance and interest of many residents of Pine County.

\section{References}

Boerboom TJ. 2001. Plate 2-Bedrock Geological Map and Sections, Geological Atlas of Pine County Minnesota, Part A, Atlas C-13. Minnesota Geological Survey, St. Paul, Minnesota.

Boerboom TJ, Runkel AC, Chandler VW. 2002. Bedrock geology of Pine County, Minnesota, Chapter 1, Boerboom TJ project manager. Contributions to the Geology of Pine County. RI 60, Minnesota Geological Survey, St. Paul, Minnesota.

Cannon WF, Daniels DL, Nicholson SW, Phillips J, Woodruff LG, Chandler VW, Morey GB, Boerboom TJ, Wirth KR, and Mudrey MG Jr. 2001. New map reveals origin and geology of North American Mid-Continent Rift. Eos 82: (97) 100-101.

Chalcraft D, Pye K. 1984. Humid tropical weathering of Quartzite in southeastern Venezuela. Zeitschrift fur Geomorphologie 28: 321-332.

Dzulynski S, Kotarba A. 1979. Solution pans and their bearing on the development of pediments and tors in granite. Zeitshrift fur Geomorphologie 23: 172-191.

Frye JC, Swineford A. 1947. Solution Features on Cretaceous Sandstone in Central Kansas. American Journal of Science 245: 366-379.
Jennings J. 1983. Sandstone pseudokarst or karst? In Young RW, Nanson GC, editors, Aspects of Australian Sandstone Landscapes. Australian and New Zealand Geomorphology Group Special Publication 1, University of Wollagong, Wollagong, Australia.p. 21-30.

Klimchouk A, Ford D. 2000. Types of Karst and Evolution of Hydrogeologic Setting. In Speleogenesis: Evolution of Karst Aquifers, Klimchouk A, Ford D, Palmer A, Dreybrodt W, editors, National Speleological Society, Alabama, 45-53.

Knaeble AR, Patterson CJ, Mayer GN. 2001. Plate 5-Quaternary Stratigraphy, Geological Atlas of Pine County Minnesota, Part A, Atlas C-13, Minnesota Geological Survey, St. Paul, Minnesota.

Mooney HM, Craddock C, Farnham PR, Johnson SH, Volz G. 1970. Refraction seismic investigation of the northern midcontinent gravity high. Journal of Geophysical Research 75: 5056-5086.

Morey GB. 1972. Petrology of Keweenaw Sandstones in the Subsurface of Southeastern Minnesota. In Sims PK, Morey GB, editors, Geology of Minnesota: A centennial volume. Minnesota Geological Survey, St. Paul, Minnesota, p. 436449.

Patterson CJ, Knaeble AR. 2001. Plate 4-Surficial Geology, Geological Atlas of Pine County Minnesota, Part A,Atlas C-13. Minnesota Geological Survey, St. Paul, Minnesota.

Shade BL. 2002a. The Genesis and Hydrogeology of a Sandstone Karst in Pine County, Minnesota [master's thesis]. Minneapolis, MN: University of Minnesota, $171 \mathrm{p}$.

Shade BL, Alexander SC, Alexander EC Jr, Martin S. 2002b.Sinkhole Distribution. Plate 6- Sinkhole Distribution, Depth to Bedrock and Bedrock Topography, Part A, Atlas C-13. Minnesota Geological Survey, St. Paul, Minnesota.

Shade BL, Alexander SC, Alexander EC Jr. 2002c. Karst Features of Pine County, Minnesota, Chapter 4, Boerboom TJ project manager. Contributions to the Geology of Pine County. RI 60, Minnesota Geological Survey, St. Paul, Minnesota.

Tipping R, Rantalla M, Alexander EC Jr, Gao Y, Green J. 2015. History and Future of the Minnesota Karst Feature Database. This volume.

Truluck TF. 1991. Deepest and Longest Caves in Africa and Southern Africa, and the Deepest Sandstone Caves in the World. Bulletin of the South American Speleological Association 32: 99-101. 
Tryhorn AD, Ojakangas RW. 1972. Sedimentation of the Hinckley Sandstone of east-central Minnesota. In Sims PK, Morey GB, editors, Geology of Minnesota: A centennial volume. Minnesota Geological Survey, St. Paul, Minnesota, p. 416-424.

Turkington, AV, Paradise, TR. 2005. Sandstone weathering; a century of research and innovation. Geomorphology 67: 229-253.

White WB. 1988, Geomorphology and Hydrology of Karst Terrains. Oxford University Press, New York, 464pp.

White WB, Jefferson GL, Haman JF. 1966. Quartzite Karst in Southeastern Venezuela. International Journal of Speleology 2: 309-314.

Wray RAL. 1997. A global review of solutional weathering forms on quartz sandstones. EarthScience Reviews 42: 137-160.

Wright HE Jr. 1964. Origin of the Lakes in the Chuska Mountains, Northwestern New Mexico. Geological Society of America Bulletin 75: 589-598.

Young RW. 1986. Tower Karst in Sandstone: Bungle Bungle massif, northwestern Australia. Zeitshrift fur Geomorpholgie 30: 189-202.

Young RW. 1987. Sandstone landforms of the tropical East Kimberley region, northwestern Australia. Journal of Geology 95: 205-218.

Young RW. 1988. Quartz etching and sandstone Karst: Examples from the East Kimberleys, Northwestern Australia. Zeitshrift fur Geomorphology 32: 409-423.

Zawidzski P, Urbani F, Koisar B. 1976. Preliminary notes on the geology of the Sarisarinama Plateau, Venezuela, and the origin of its caves. Boletain de la Sociedad Venezolana de Espeleogaia 7: 29-37. 